Journal of Teacher Education for Sustainability, vol. 19, no. 1, pp. 69-81, 2017

\title{
Sustainability Reporting at Schools: Challenges and Benefits
}

\author{
Eva Carbach and Daniel Fischer \\ Leuphana University of Lüneburg, Germany
}

\begin{abstract}
Despite advances made there is still an implementation gap with regard to Education for Sustainable Development (ESD) in formal educational systems at the school level. The present paper focuses on sustainability reporting as a recently emerging practice in the school sector. It presents the approach and findings of an exploratory interview study at three pioneer schools in Germany that have started to establish sustainability reporting mechanisms. The study has examined how the reporting process is evaluated by project managers with regard to its benefits and challenges. Findings support the potential of sustainability reporting at schools to contribute to an increase in students' participation in sustainability-related activities at school, create accountability concerning the school's efforts, help structure the existing sustainability projects and demonstrate new possible courses of action. The high expenditure of time, the teachers' high workload and lack of support given to the teachers have been identified as major challenges of the reporting process. Further directions for future research into reporting practices at schools are given. Keywords: Sustainability reporting, school development, Education for Sustainable Development.
\end{abstract}

\section{Introduction}

A key theme in the debate about Education for Sustainable Development (ESD) relates to the issue of how educational institutions should respond to the challenges posed by the idea of sustainability. The final report of the United Nations World Decade on ESD has found that in the community of scholars and practitioners closely associated to UNESCO most experts favour approaches that seek to deeply integrate ESD or even use it as a guiding idea for the redesign of the educational system rather than to merely add parts of ESD to existing practices (Kalaitzidis, 2013; Wals, 2012; Lukk, Veisson \& Ots, 2008). In line with this, it can be observed that ESD is strongly responsive to the trends in general educational policy towards promoting school autonomy and expanding school-community interlinkages in many countries, particularly in Europe (Christ \& Dobbins, 2016, Million, Heinrich \& Coelen, 2015).

The main aims pursued with these activities are to improve and enhance students' educational experience by comprehensively focusing on all facets of a school's learning and teaching settings and the broader landscape of institutions offering learning experiences. 
This is particularly reflected in UNESCO Global Action Programme (GAP) (UNESCO, 2014). In two of its five priority action areas (numbers 2 and 5), it places special emphasis on the conception of schools as elements in broader educational landscapes and on the need to develop educational institutions not only with regard to formal teaching, but more broadly by considering campus, curriculum and community. In this spirit, several national and international initiatives have sought to advance different networks of sustainable schools (Rickinson, Hall \& Reid, 2015; Lysgaard, Larsen \& Læssøe, 2015; Ilisko \& Badyanova 2014; Cincera \& Krajhanzl, 2013). Likewise in academia, wholeschool approaches to the incorporation of sustainability into the educational institutions' structures and practices have attracted increasing attention in the field of ESD research (Salter, 2015; Barth, Fischer, Michelsen, Nemnich \& Rode, 2012).

With this increased attention on school holistic sustainability performance, two major challenges for schools arise. Many schools are still struggling to advance from a stage of experimenting with and assimilating to ESD on a project basis (also referred to as a bolt-on approach) to a more structural and strategic incorporation of ESD into the school's mission (built-in approach) (Sterling \& Thomas, 2006). Hence, the first challenge is to explore appropriate tools and approaches capable of uplifting fragmented activities towards more integrated efforts. The second challenge is closely related to this. The growing awareness of ESD as a future-oriented educational concept that prepares learners for the challenges of the $21^{\text {st }}$ century challenges schools to account for the ways and the extent to which they actually engage with sustainability issues.

Sustainability reporting represents an established and well-elaborated approach to address both challenges. It allows organisations to communicate how it is performing, what strategy it is pursuing and what goals it is steering toward. Furthermore, it has been shown to be able to establish a process of integrating existing activities and developing these further in a more concerted approach. Sustainability reporting has initially emerged in the business sector and then increasingly spilled over also into the public sector (Kolk, 2003; Dumay, Guthrie, \& Farneti, 2010; Thijssens, Bollen \& Hassink, 2016). Higher education institutions have been first to respond to this trend in the education sector, with several elaborated assessment and reporting schemes and systems in place today (Ceulemans, Molderez, \& van Liedekerke, 2015; Fischer, Jenssen, \& Tappeser, 2015). In the literature on higher education for sustainable development, sustainability reporting is conceived to perform several different functions. In particular, it is used to analyse the ongoing sustainability performance, discover potential for improvement and help derive further measures from them (Lozano, 2006; Adomßent \& Michelsen, 2006). In the primary and secondary school sector, however, there is an apparent paucity of research on how sustainability reporting has been used as an instrument in the context of whole-school development towards sustainability. The present paper addresses this research gap and offers a qualitative exploration into the experiences of German frontrunner schools that have published a sustainability report. This study seeks to identify benefits and challenges that school actors perceive to come with publishing a sustainability report. By pursuing this question, the research presented advances the understanding to what extent sustainability reporting as an approach to whole-school development can help to implement ESD comprehensively in schools.

In what follows, we will provide some context to the study by giving a brief introduction into existing approaches to implement ESD in the German school system and into the role that communication and reporting play so far. 


\section{Background: ESD in the German School System}

In Germany, several political declarations and statements reaffirm the importance that is ascribed to the promotion of a comprehensive engagement with ESD in public schools. A prominent example is a joint declaration of the Standing Conference of the Ministers of Education and Cultural Affairs (KMK) and the German Commission for UNESCO (DUK) that admits the implementation of the concept of ESD in German schools (Deutsche UNESCO-Kommission (DUK) \& Kultusministerkonferenz (KMK), 2007). The release of an action plan for the national implementation of UNESCO GAP is announced for spring 2017. Despite this political backing from the federal level, the implementation of ESD has been impeded by the specific conditions of the education system in the past decade. The public school system in Germany is substantially shaped by the distribution of authorities and competencies between the state and the federal levels. The federalism reform enacted in 2006 has strengthened the role of the 16 states that since then have been bearing the sole responsibility for the public school system in their territories. This situation has resulted in a number of different school types (e.g., comprehensive secondary schools) and different lengths of educational phases (e.g., four or six years of primary education) among the states. One of the remaining leverage points at the federal level is to promote innovations through the major pilot programmes. Examples for the major federal initiatives promoting the implementation of ESD in public schools are BLK-21 and TRANSFER-21 (Haan, 2006) and the activities implemented under the umbrella of the UN Decade. In a more decentralised manner, ESD has also been promoted by more self-sustained national and international networks, such as the European ENSI network (Breiting, Mayer \& Mogensen, 2005). It can be stated that communication and reporting have been addressed as pivotal domains in these programmes, in particular with regard to self-evaluation and auditing (Transfer-21 'Quality and Competencies' Working Group, 2007). While the documentation and communication of self-evaluation and auditing indeed reflect key functions of sustainability reporting, the systematic effort of compiling and utilising sustainability reports has not been given much if any consideration. Likewise, and despite considerable progress made, the situation today is still characterised by a lack of institutionalisation: ESD has not been prominently featured so far in school inspection schemes or as a compulsory crosscurricular theme and its implementation in a whole-school approach is at best encouraged. The adoption of ESD in schools still depends to a significant extent on the initiative of engaged actors within the system (Kolleck, 2015; Schellenbach-Zell \& Gräsel, 2010). Hence, in order to implement ESD in the German School System, effective methods and instruments are needed.

\section{Study Design}

\section{Research Question}

In light of (1) the search for approaches to engage schools to systematically adopt ESD in the whole-institution perspective and (2) the lack of research on the practice of sustainability reporting in German public schools, the following research question has been framed for the study: How is sustainability reporting at schools evaluated by project managers with regard to its benefits and challenges? 


\section{Methods}

The present study focuses on German schools that have already published a sustainability report. Given the lack of studies in this research field, this study is of an explorative character. In order to convey an open and nonbiased perspective on what people in charge of drafting the school sustainability report perceive as benefits and challenges of sustainability reporting at schools, a qualitative research approach has been followed. The developed approach comprises the following three steps: (1) the internet research to identify front-runner schools that have published a sustainability report, (2) a questionnaire sent to these schools in order to gain additional background information for final sampling, and (3) expert interviews with selected case schools. As steps 1 and 2 aim at defining a selection of schools for an in-depth analysis, they will be presented together in the further sections as the sampling approach underpinning this study.

\section{Sampling}

As the first step, the internet search was performed to identify existing sustainability reports published by schools. Inclusion criteria for this step were as follows: (a) the document had to be explicitly self-referenced as a sustainability report (Prexl, 2010), (b) it was issued officially by a public school in Germany and (c) the persons responsible for the reporting process were still available. In total, ten schools were identified in this step.

In the second step, a questionnaire was given to all ten schools in order to collect additional background information on the institution and the process of sustainability reporting. The schools were asked to report on who initiated the development of a sustainability report (multiple selections from a total of eight different stakeholder groups), the level of student involvement in the reporting process (4-point Likert scale from very low to very high) and number of people involved (open answer). Additionally, the type of school and the number of sustainability reports published were noted. The questionnaire was returned by eight schools (see Table 1).

Table 1

Sampling Criteria

\begin{tabular}{|c|c|c|c|c|c|c|}
\hline & $\begin{array}{l}\text { Type of } \\
\text { school }\end{array}$ & $\begin{array}{l}\text { Student } \\
\text { particip- } \\
\text { ation } \\
\end{array}$ & $\begin{array}{l}\text { Type of } \\
\text { initiator }\end{array}$ & $\begin{array}{c}\text { Published } \\
\text { sustainability } \\
\text { reports } \\
\end{array}$ & $\begin{array}{c}\text { Number of } \\
\text { involved } \\
\text { people }\end{array}$ & $\begin{array}{c}\text { Included } \\
\text { in final } \\
\text { sample }\end{array}$ \\
\hline School 1 & $\begin{array}{l}\text { Vocational } \\
\text { college }\end{array}$ & Low & $\begin{array}{l}\text { Teacher, external } \\
\text { organisation }\end{array}$ & 2 & 15 & \\
\hline School 2 & Elementary & Very low & Parents & 3 & 1 & $\mathrm{X}$ \\
\hline School 3 & Elementary & Low & Principal & 1 & 18 & \\
\hline School 4 & $\begin{array}{l}\text { Vocational } \\
\text { college }\end{array}$ & High & $\begin{array}{l}\text { Teacher, external } \\
\text { company }\end{array}$ & 2 & no answer & \\
\hline School 5 & $\begin{array}{l}\text { Upper } \\
\text { secondary } \\
\text { (Gymnasium) }\end{array}$ & Very high & $\begin{array}{l}\text { Teacher, parents, } \\
\text { principal, } \\
\text { student }\end{array}$ & 1 & 3 & \\
\hline School 6 & $\begin{array}{l}\text { Upper } \\
\text { secondary } \\
\text { (Gymnasium) }\end{array}$ & Very high & Teacher, student & 2 & 19 & $\mathrm{X}$ \\
\hline
\end{tabular}




\begin{tabular}{|c|c|c|c|c|c|c|}
\hline & & & & & \multicolumn{2}{|c|}{ Sequel to Table } \\
\hline School 7 & $\begin{array}{l}\text { Lower } \\
\text { secondary } \\
\text { (Realschule) }\end{array}$ & Low & $\begin{array}{l}\text { Teacher, parents, } \\
\text { principal, student, } \\
\text { external company }\end{array}$ & 1 & 2 & $\mathrm{X}$ \\
\hline School 8 & $\begin{array}{l}\text { Lower } \\
\text { secondary } \\
\text { (Realschule) }\end{array}$ & Very high & $\begin{array}{l}\text { Teacher, parent, } \\
\text { students }\end{array}$ & 2 & no answer & \\
\hline
\end{tabular}

Three schools were selected for further in-depth examination. The selection was made on the basis of purposeful sampling in diverse case mode (Seawright \& Gerring, 2008). In this sampling approach, cases are selected that represent the greatest possible variance along pre-determined variables. In our case, we were particularly interested in variations in student participation, types of initiators and type of school. The three schools reflecting diverse cases along these dimensions were schools 2, 6 and 7 (final sample).

\section{Expert Interviews}

In each school, within the final sample semi-structured expert interviews were conducted to gain insight into the experiences made with the reporting process and explore perception of benefits and challenges. According to Meuser \& Nagel (2009), experts are characterised by distinct and accessible knowledge in the limited area of interest. A unique feature of expert knowledge is that it is "linked with the power of defining the situation" (ibid.: 18). School-based sustainability reporting is a premature field of action for which no established procedures or standards are available. Thus, individuals in charge of managing the reporting process at school inevitably have to develop an understanding of what a sustainability report is all about and how it has to be developed within the organisational setting of the educational institution. For that reason, we carried out expert interviews with the project managers in each selected school: a parent (school 2), a teacher (school 6) and an assistant principal (school 7).

The interview guide was developed, taking into account previous qualitative studies on the implementation of sustainability at higher education institutions, whose informants were encouraged to report on their experiences in the chronological order of the implementation process and share their experiences and reflections (Barth, 2013, Disterheft, Caeiro, Azeiteiro, \& Filho, 2015). The first part of the interview guide sought to provide a more descriptive account of contextual factors, while the questions of the second part aimed at stimulating reflection and evaluation of benefits, challenges and lessons learnt. The interview guide was further refined through a dimensional analysis of potentially relevant components in each topic (Kools, McCarthy, Durham, \& Robrecht, 1996). The resulting topics included in the interview guide were not distinct, but rather overlapping. The interview guide was designed to ensure comparability of different interviews and guarantee that all relevant topics were addressed in each interview. The order of questions, however, was adapted to the interview situation and the informants' responses in order to ensure a natural conversational setting and stimulate rich narratives. The interview guide was pre-tested before the expert interviews were conducted. The interviews, of 30-60 minutes each, were fully audio-taped and transcribed. Anonymity was preserved by the use of pseudonyms. 
Table 2

Interview Guide

\begin{tabular}{|c|c|c|}
\hline Topic & Aspect / Question & Sub-aspect / Sub-question \\
\hline \multirow[t]{3}{*}{ Initial situation } & $\begin{array}{l}\text { 1. What inspired you to develop a sustainability } \\
\text { report? }\end{array}$ & \\
\hline & $\begin{array}{l}\text { 2. What was the feedback at school concerning } \\
\text { the idea of publishing a sustainability report? }\end{array}$ & \\
\hline & $\begin{array}{l}\text { 3. Who was defined as the target audience of } \\
\text { the sustainability report? }\end{array}$ & $\begin{array}{l}\text { - internal stakeholders } \\
\text { (school community) } \\
\text { - external stakeholders }\end{array}$ \\
\hline \multirow{5}{*}{$\begin{array}{l}\text { Organisation of } \\
\text { the process } \\
\text { (internal/ } \\
\text { external) }\end{array}$} & 4. How was the reporting process organised? & $\begin{array}{l}\text { - Who was the organiser? } \\
\text { - Who was involved? }\end{array}$ \\
\hline & $\begin{array}{l}\text { 5. How did you select the content of the } \\
\text { sustainability report? }\end{array}$ & \\
\hline & 6. How did you collect the data for the report? & \\
\hline & $\begin{array}{l}\text { 7. How do you evaluate the effort of publishing } \\
\text { the sustainability report? }\end{array}$ & $\begin{array}{l}\text { - financial } \\
\text { - personal } \\
\text { - temporal }\end{array}$ \\
\hline & $\begin{array}{l}\text { 8. How do you evaluate the catalogue of } \\
\text { measures, which is part of the sustainability } \\
\text { report? }\end{array}$ & \\
\hline \multirow[t]{2}{*}{ Cooperation } & $\begin{array}{l}\text { 9. Which internal stakeholders were involved in } \\
\text { the reporting process and how do you evaluate } \\
\text { their involvement? }\end{array}$ & $\begin{array}{l}\text { - type and intensity of } \\
\text { involvement (e.g., consult- } \\
\text { ation, data assessment) }\end{array}$ \\
\hline & $\begin{array}{l}\text { 10. Which external stakeholders were involved } \\
\text { in the reporting process and how do you evaluate } \\
\text { their involvement? }\end{array}$ & $\begin{array}{l}\text { - type and intensity of } \\
\text { involvement (e.g., consult- } \\
\text { ation, data assessment) }\end{array}$ \\
\hline \multirow[t]{2}{*}{ Challenges } & $\begin{array}{l}\text { 11. What were the largest obstacles in the } \\
\text { reporting process? }\end{array}$ & $\begin{array}{l}\text { - internal } \\
\text { - external } \\
\text { - financial } \\
\text { - personal } \\
\text { - structural } \\
\text { - organisational }\end{array}$ \\
\hline & $\begin{array}{l}\text { 12. Which kind of additional support would } \\
\text { you have appreciated in the reporting process? }\end{array}$ & \\
\hline Benefits & $\begin{array}{l}\text { 13. Which kind of positive effects resulted from } \\
\text { the reporting process? }\end{array}$ & $\begin{array}{l}\text { - school management } \\
\text { - networking } \\
\text { - public relations } \\
\text { - participation } \\
\text { - organisational identity } \\
\text { - transparency }\end{array}$ \\
\hline \multirow[t]{3}{*}{ Outlook } & $\begin{array}{l}\text { 14. Looking back on your experiences, what } \\
\text { would you change if you were to go through the } \\
\text { process again? }\end{array}$ & \\
\hline & $\begin{array}{l}15 . \text { How far were your expectations regarding } \\
\text { the reporting process met? }\end{array}$ & \\
\hline & $\begin{array}{l}\text { 16. Based on your experiences, what does it take } \\
\text { to implement sustainability at schools in the } \\
\text { long run? }\end{array}$ & \\
\hline
\end{tabular}


The interview transcripts were processed according to the data analysis procedure for expert interviews developed by (Meuser \& Nagel, 2009). In its main steps, the procedure reflects other well-established approaches to qualitative data analysis, such as thematic analysis (Braun \& Clarke, 2006) or qualitative content analysis (Mayring, 2004). The purpose of the analysis is to identify similar topics and compare the different expert statements with regard to their meaning and significance, whilst particularly taking into account their organisational and institutional context. In the first step of the analysis the transcript is paraphrased. Then the material is condensed by sorting the information into passages with headings that are relevant to the research question, i.e., the experiences of project managers concerning benefits and challenges in establishing a sustainability reporting process at a school. The next step (thematic comparison) expands the focus from single passages of individual transcripts to overarching patterns in the entire material. In this step, text passages from each interview addressing similar themes are pooled and subsequently compared to each other in order to identify similarities and differences. While the aforementioned steps take place within the boundaries of the empirical material, the next step (sociological conceptualisation) now explicitly seeks to review the themes and patterns found in light of theoretical knowledge and academic discourse. The main purpose in this step is to generalise the empirical material by rephrasing it in scholarly terminology. Finally, the analysis is completed by theoretical generalisation. Here, the new findings from the prior steps are contextualised within and connected to general theories in the field.

\section{Findings and Discussion}

According to the research question, our analysis focuses on identifying perceived benefits and challenges in the process of developing a sustainability report at schools. As a result, we have found two major topics referring to challenges and four major topics referring to benefits. The challenges have been grouped into implementation challenges and challenges caused by external restrictions. Benefits of sustainability reporting have been grouped into benefits for the participants, for the school management, for networking and public relations, and for sustainable living. In what follows, the findings are presented in detail.

\section{Challenges}

\section{Implementation}

All experts participating in the interview (subsequently referred to as informants) noted that the establishment of a sustainability reporting process at school was a very time-consuming endeavour and mentioned that it was not always easy to allocate the necessary time resources for the project. When the project managers were asked to generally comment on the perceived barriers, they mentioned that time was a "problem" (informant 2) and "it was not easy to devote the required time" (informant 3). One informant summarised that an engagement in sustainability reporting put significant personal demands on those involved: "it consumed energy" (informant 1).

Two of the respondents also voiced the opinion that further difficulties were imposed by the unresolved issue of continuing the process started by implementing a sustainability 
reporting mechanism. A matter of concern for the informants here was the issue of how sustainability reporting could be integrated in the daily school curriculum and how it could be permanently implemented and maintained at schools, irrespective of students and teachers.

Additionally, every project had problems with data collection. One informant referred to the observation that "there were some data which you could not collect in a statistical way" (informant 1). Another issue was data availability: some data were difficult to obtain, while other data, for example, were not granted to the school by public utility companies. Informants noted that these difficulties made data collection a time-consuming process and also led to poor data quality, making the result less representative and not as accurate. Moreover, due to technical and security reasons the students were not allowed to participate in meter reading. Furthermore, data processing and presentation showed to bear some difficulties when the reporting process involved students, as "they first had to learn how to represent the collected data into aggregated charts" (informant 2).

Another obstacle was the lack of motivation and support. All of the interviewed informants tried to receive assistance from other teachers, parents and the school management. However, they found that "it was not easy to motivate other teachers to participate in the project because there were no incentives" (informant 1), and parents were not very supportive in the process (informant 2 ). This did not only refer to an active engagement in the process, but also to some essential contributions as experienced in one case in the form of low response rates of a questionnaire administered as part of the data collection (informant 2). Another challenge was the acquisition of additional financial funds to make the sustainability report available to every student (school 2) or to pay the teachers involved in the development of the report (school 1). These struggles for financial and human resources were responsible for an overall downturn in the project manager's personal motivation to continue work on the sustainability report (informant 3).

Overall, the feedback on the sustainability report from the internal school partners and the external stakeholders was perceived as positive by the informants. However, in one case several teachers noted their displeasure that students asked the teachers and the caretaker about their salary and published the information in the report. Informants 2 and 3 found it unfortunate that not all of the students and parents were aware of the sustainability reporting process and argued for a better stakeholder communication.

\section{External Restrictions}

Challenges arising from external restrictions relate to conditions and circumstances that constitute the context of the sustainability reporting process. Time and workload feature as prominent challenges here, too. Unlike before, however, this was referred to as a structural constraint and not a specific experience related to the sustainability reporting process. It was mentioned that the high workload of teachers and students leave little room for extra activities. As one specific root cause, the informants noted that the administrative and bureaucratic obligations at school are generally high and have a paralysing effect on projects requiring additional work, such as the establishment of a sustainability reporting process at schools. This situation can be illustrated by a 
statement made by informant 1 who noted: "the administration crap eats you up". Another more structural condition perceived as a challenge was that despite prominent political affirmations and proclamations, ESD is rather marginalised in the school reality. In the experience of informant 3, ESD has not been established yet as an essential "part of the normal school curriculum and is seen as extra work rather than normal school work". Rather low significance attributed to ESD by the school stakeholders provides a rather fragile ground for the project and fails to promote a stronger sense of legitimacy.

\section{Benefits}

\section{Participants}

The informants who participated in the reporting process experienced several benefits. It was noted by all informants that being part of the development of the sustainability report filled the participating students with a sense of pride. In all three cases, this was associated with increasing interest among students in how the school embraces and engages in sustainability issues, particularly in its operations. In one case, students were given the responsibility to develop the sustainability report. Consequently, students had to decide on which aspects they wanted to focus in the reporting process. This enabled the students to assess information about the school which was normally not overt or even accessible to them. The experiences of managing the reporting process autonomously translated into several learning outcomes for the students (informant 2). One particular effect that was observed was that "the teamwork encouraged solidarity among students" (informant 1). All three informants claimed that the development of the sustainability report enhanced personal well-being, as the invested efforts resulted in a tangible product that was widely accessible and reflected the achievements that their school had accomplished with regard to the promotion of sustainable development and ESD.

\section{School Management}

The sustainability report was also perceived to have positive effects on school management. In all three cases, the sustainability report provides guidance and orientation as it indicates fields that require further action and highlights achievements that have been accomplished and need to be maintained. It was mentioned as a distinct benefit of the reporting process that it helped link the different school projects with one another and show how they fuelled into a broader cause of promoting sustainable development. According to our informants, this helped different school stakeholders to identify more strongly with the school. The mapping of activities also allowed the school actors to "see where there was a lack of cooperation between similar projects" (informant 1). That way, the reporting process helped structure school development activities and define further goals. This prospective commitment to improve the reported status quo was illustrated by a statement of informant 1: "sustainability reporting means not only that's we are, it is also a question of where we wanna go". 


\section{Networking and Public Relations}

A cross-cutting issue in the experiences expressed by our informants is the potential of sustainability reporting to encourage networking with different stakeholders. This involves both the direct participation of stakeholders in the process of developing the sustainability report and the indirect consideration of stakeholders by covering their activities or drawing on their data (e.g., surveys, technical data). In addition to this benefit, the sustainability report itself serves as a platform that encourages different internal and external stakeholders to position themselves and engage in setting new goals and deciding on the future course of the school. An additional benefit in this domain that all informants referred to was that releasing a sustainability report attracted public attention. Informant 2 reported, for example: "The Federal Ministry of Education and Research has invited us to present the project of our school at a congress about resources protection in September". Some schools even received awards and recognition for their efforts to become a sustainable school, which in turn also helped the school to increase its reputation and distinguish itself from other schools through a distinct profile.

\section{Sustainable Living}

According to the informants, the school engagement in sustainability reporting has had a sensitising effect insofar as it "strengthens the awareness of sustainability" (informant 2). Our informants observed an increase in accountability both in terms of more sustainable school management (informant 1 ) and with respect to more sustainable consumption practices of teachers and students (informant 2), in particular concerning water and energy consumption as well as mobility. This awareness raising effect was not limited to the margins of a single school, but also created a momentum or interest among other schools. In this respect, our informants perceived the process of documenting and reporting sustainability activities at schools as an encouraging activity that could promote other schools to engage in sustainability issues and start their own projects.

\section{Outlook and Conclusion}

The starting point of the present paper has been an apparent paucity of examples for sustainability reporting initiatives in the school sector in Germany. This research gap has been addressed with an exploratory empirical study of three project managers' experiences related to implementing sustainability reporting at schools. Our analysis has revealed some overall challenges and benefits. The major challenges and obstacles mentioned by the project managers are lack of time and high workload of teachers that seriously impede the implementation of a systematic sustainability reporting scheme at schools. Moreover, difficulties are also related to data collection. The main benefits of sustainability reporting are networking opportunities and increased public visibility, greater transparency with regard to achievements and needs for action, new and authentic learning settings for students and student participation, as well as greater organisational and personal commitment to sustainability in the school life.

What seems striking is that several benefits associated with sustainability reporting are not restricted to sustainable development or ESD, but rather with generic value related to school quality and school development (e.g., networking and participation). 
This finding suggests that the value of sustainability reporting should not be reduced to its potential to make schools more sustainable. Thus, it can also be used to achieve general educational rather than sustainability-specific purposes. The analysis has also revealed some barriers that educators and policy-makers should overcome in order to create more enabling conditions for mainstreaming sustainability reporting practices in the school sector. More favourable conditions may include additional grants/funds, the utilisation of external resources and expertise and, more generally, a reduction of bureaucracy that will allow teachers to engage more intensively in projects targeting the whole institution and take part in extracurricular, cross-cutting activities such as sustainability reporting.

To sum up, the findings of our exploratory study suggest that the potential of sustainability reporting closely corresponds to broader direction that ESD is heading as outlined by the priority action areas of UNESCO Global Action Programme. Sustainability reporting can be designed as a highly participatory and engaging process; it conveys a whole-institution perspective and provides opportunities for networking and outreach into a broader educational landscape. It thus seems worthwhile to engage more intensively in sustainability reporting as an enabling mechanism in the implementation of the next phase of ESD. Promising approaches to substantiate this field further are transdisciplinary projects that combine practical experimentation on the basis of critical analysis and reflection.

\section{References}

Adomßent, M., \& Michelsen, G. (2006). German Academia heading for sustainability? Reflections on policy and practice in teaching, research and institutional innovations. Environmental Education Research, 12(1), 85-99.

Barth, M. (2013). Many roads lead to sustainability: A process oriented analysis of change in higher education. International Journal of Sustainability in Higher Education, 14(2), 160-175.

Barth, M., Fischer, D., Michelsen, G., Nemnich, C., \& Rode, H. (2012). Tackling the knowledge-action gap in sustainable consumption: Insights from a participatory school programme. Journal of Education for Sustainable Development, 6(2), 135146.

Braun, V., \& Clarke, V. (2006). Using thematic analysis in psychology. Qualitative Research in Psychology, 3(2), 77-101.

Breiting, S., Mayer, M., \& Mogensen, F. (2005). Quality criteria for ESD-schools. Guidelines to enhance the quality of education for sustainable development. Vienna.

Ceulemans, K., Molderez, I., \& van Liedekerke, L. (2015). Sustainability Reporting in Higher Education. A comprehensive review of the recent literature and paths for further research. Journal of Cleaner Production, 106(0), 127-143.

Christ, C., \& Dobbins, M. (2016). Increasing school autonomy in Western Europe. A comparative analysis of its causes and forms. European Societies, 18(4), 359-388.

Cincera, J., \& Krajhanzl, J. (2013). Eco-Schools: What factors influence pupils' action competence for pro-environmental behaviour? Journal of Cleaner Production, 61, 117-121. 
Deutsche UNESCO-Kommission (DUK) \& Kultusministerkonferenz (KMK). (2007). Empfehlungen zur "Bildung für nachhaltige Entwicklung in der Schule”, Bonn.

Disterheft, A., Caeiro, S., Azeiteiro, U. M., \& Filho, W. L. (2015). Sustainable universities - A study of critical success factors for participatory approaches. Journal of Cleaner Production, 106, 11- 21.

Dumay, J., Guthrie, J., \& Farneti, F. (2010). GRI sustainability reporting guidelines for public and third sector organizations. Public Management Review, 12(4), 531-548.

Fischer, D., Jenssen, S., \& Tappeser, V. (2015). Getting an empirical hold of the sustainable university: a comparative analysis of evaluation frameworks across 12 contemporary sustainability assessment tools. Assessment \& Evaluation in Higher Education, 40(6), 785-800.

Haan, G. de. (2006). The BLK '21' programme in Germany: a 'Gestaltungskompetenz'based model for Education for Sustainable Development. Environmental Education Research, 12(1), 19-32.

Iliško, D., \& Badjanova, Y. (2014). A case study of ESD implementation: Signs of sustainable leadership. Discourse and Communication for Sustainable Education, $5,38-48$.

Kalaitzidis, D. (2013). Sustainable school indicators: Approaching the vision through the sustainable school award. Journal of Teacher Education for Sustainability, $14(2), 168-180$.

Kolk, A. (2003). Trends in sustainability reporting by the Fortune Global 250. Business Strategy and the Environment, 12(5), 279-291.

Kolleck, N. (2015). Uncovering influence through Social Network Analysis. The role of schools in Education for Sustainable Development. Journal of Education Policy, 31(3), 308-329.

Kools, S., McCarthy, M., Durham, R., \& Robrecht, L. (1996). Dimensional analysis. Broadening the conception of grounded theory. Qualitative Health Research, 6(3), 312-330.

Lozano, R. (2006). Incorporation and institutionalization of SD into universities: Breaking through barriers to change. Journal of Cleaner Production, 14(9-11), 787-796.

Lukk, K., Veisson, M., \& Ots, L. (2008). Characteristics of sustainable changes for schools. Journal of Teacher Education for Sustainability, 9, 35-44.

Lysgaard, J. G., Larsen, N., \& Læssøe, J. (2015). Green flag eco-schools and the challenge of moving forward. In V. W. Thoresen, D. Doyle, J. Klein \& R. J. Didham (Eds.), Responsible Living. Concepts, Education and Future Perspectives (pp. 135-150). Dordrecht: Springer.

Mayring, P. (2004). Qualitative Content Analysis. In U. Flick, E. von Kardorff, \& I. Steinke (Eds.), A Companion to Qualitative Research (pp. 266-269). London: SAGE.

Meuser, M., \& Nagel, U. (2009). The expert interview and changes in knowledge production. In A. Bogner, B. Littig \& W. Menz (Eds.), Interviewing Experts (Research methods series, pp. 17-42). Basingstoke: Palgrave Macmillan.

Million, A., Heinrich, A. J., \& Coelen, T. (2015). Educational landscapes and urban development. contextual and spatial interfaces and linkages. Planning Practice $\&$ Research, 30(5), 587-601.

Prexl, A. (2010). Nachhaltigkeit kommunizieren - nachhaltig kommunizieren. Analyse des Potenzials der Public Relations für eine nachhaltige Unternehmens- und Gesellschaftsentwicklung. Wiesbaden: VS Verlag. 
Rickinson, M., Hall, M., \& Reid, A. (2015). Sustainable schools programmes. What influence on schools and how do we know? Environmental Education Research, 22(3), 360-389.

Salter, Z. (2015). Impact of whole-school education for sustainability on upper-primary students and their families. Environmental Education Research, 22(3), 436-437.

Schellenbach-Zell, J., \& Gräsel, C. (2010). Teacher motivation for participating in school innovations - supporting factors. Journal for Educational Research Online, 2(2), 34-54.

Seawright, J., \& Gerring, J. (2008). Case selection techniques in case study research. A menu of qualitative and quantitative options. Political Research Quarterly, 61(2), 294-308.

Sterling, S. \& Thomas, I. (2006), Education for sustainability: the role of capabilities in guiding university curricula, International Journal of Innovation and Sustainable Development, 1(4), 349-370.

Thijssens, T., Bollen, L., \& Hassink, H. (2016). Managing sustainability reporting. Many ways to publish exemplary reports. Journal of Cleaner Production, 136, 86101.

Transfer-21 'Quality and Competencies’ Working Group. (2007). Developing Quality at "ESD Schools” Quality Areas, Principles \& Criteria, Berlin.

UNESCO. (2014). Roadmap for Implementing the Global Action Programme on Education for Sustainable Development. Paris: UNESCO.

Wals, A. E. J. (2012). Shaping the Education of Tomorrow. 2012 Full-length Report on the UN Decade of Education for Sustainable Development. Paris: UNESCO.

Correspondence concerning this paper should be addressed to Eva Carbach, Leuphana University of Lüneburg, Scharnhorststr. 1, 21335 Lüneburg, Germany. Email: eva.carbach@stud.leuphana.de 